\title{
収縮期最大血流速度を用した内頸動脈狭窄診断における ドプラ入射角度補正の検討
}

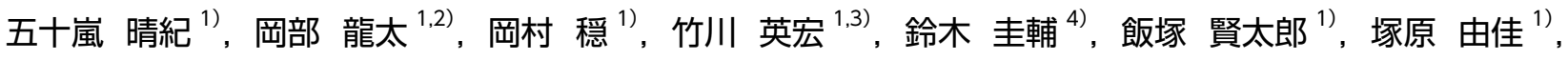 \\ 西平 崇人 ${ }^{1)}$, 鈴木 綾乃 $^{1)}$, 岩崎 晶夫 ${ }^{1)}$, 平田 幸一 ${ }^{4)}$ \\ 1) 獨協医科大学神経内科脳卒中部門 \\ 2) 公立阿伎留医療センタ一循環器内科 \\ 3) 獨協医科大学病院超音波センター \\ 4) 獨協医科大学神経内科
}

\section{Influence of Doppler angle on peak systolic velocity for diagnosis of internal carotid artery stenosis}

\author{
Haruki IGARASHI $^{1)}$, Ryuta OKABE ${ }^{1,2)}$, Madoka OKAMURA ${ }^{1)}$, Hidehiro TAKEKAWA ${ }^{1,3)}$, \\ Keisuke SUZUKI $^{4)}$, Kentaro IIZUKA ${ }^{1)}$, Yuka TSUKAHARA ${ }^{1)}$, Takahito NISHIHIRA ${ }^{1)}$, \\ Ayano SUZUKI $^{1)}$, Akio IWASAKI ${ }^{1)}$, Koichi HIRATA ${ }^{4)}$ \\ 1) Stroke Division, Department of Neurology, Dokkyo Medical University \\ 2) Department of Cardiology, Akiru Municipal Medical Center \\ 3) Center of Medical Ultrasonics, Dokkyo Medical University \\ 4) Department of Neurology, Dokkyo Medical University
}

\begin{abstract}
Objective: The jet flow direction at the stenotic lesion is not always parallel to the blood vessel direction. Therefore, we examined the optimal angle correction.

Methods: Among 50 subjects with stenosis at the internal carotid artery (ICA) bifurcation who underwent carotid ultrasonography and digital subtraction angiography (DSA). The measurement of peak systolic velocity (PSV) at the stenotic lesion site was performed according to the guideline of Japan Academy of Neurosonology. The subjects were divided into 2 groups: group A, angle was aligned parallel to the blood flow at the stenotic lesion $(n=23)$ and group $B$, angle was aligned parallel to the blood vessel $(n=30)$. ICA stenosis was diagnosed on DSA images according to NASCET criteria.

Results: In groups A and B, there was a significant correlation between PSV and stenosis ratio. In diagnosing ICA stenosis $(\geq 70 \%)$, the area under ROC curve, the sensitivity and specificity of PSV were $0.973,100 \%$ and $85.7 \%$ with a cutoff level of $203.5 \mathrm{~cm} / \mathrm{s}$ and $0.765,70.0 \%$ and $80.0 \%$ with a cutoff level $256.9 \mathrm{~cm} / \mathrm{s}$, respectively.

Conclusion: Our study suggests the angle-adjustment towards the blood flow at the stenotic lesion site is superior to the angle-adjustment parallel to the blood vessel for PSV measurement.
\end{abstract}

Keywords: peak systolic velocity, carotid ultrasonography, carotid artery stenosis

(Received March 14, 2017; Accepted April 13, 2017)

\section{はじめに}

内頸動脈狭窄症の診断は, 脳血管撮像 (digital subtraction angiography：DSA）がゴールドスタンダードで あるが，造影剤やDSAによる合併症の危険性が少ない
ながらも懸念される ${ }^{1,2)}$. そのため非侵襲的な頸動脈工 コー検査による内頸動脈狭窄の評価がスクリーニングと して広く普及している。頸動脈エコー検査での内頸動脈 狭窄診断には，狭窄部長軸断面または短軸断面による径 狭窄率，短軸断面による面積狭窄率のほか，パルスドプ 


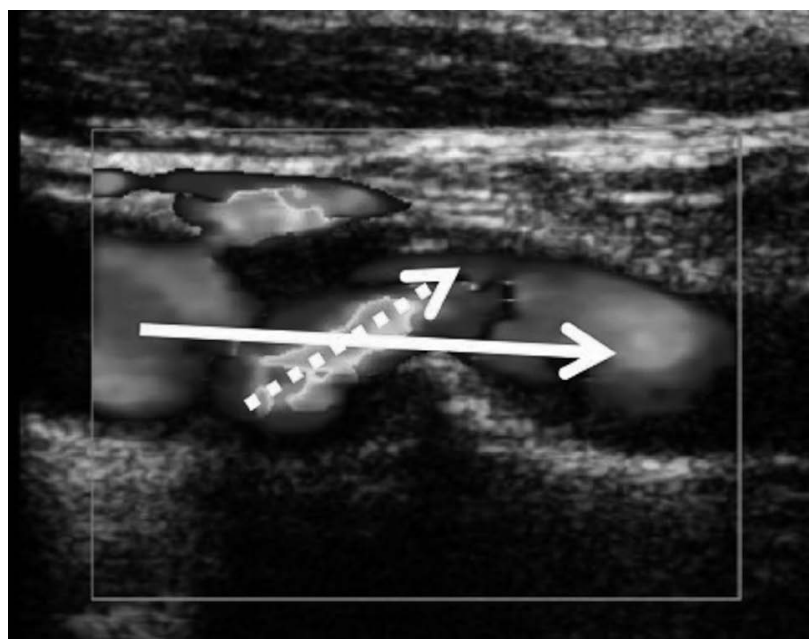

Fig.1 Measurement of peak systolic velocity

The angle was aligned parallel to the blood vessel (solid line) for the angle-adjustment towards the blood vessel group and to the blood vessel (dotted line) for the angle-adjustment towards the blood flow group.

ラ法を用いた狭窄部の収縮期最大血流速度（peak systolic velocity：PSV）の増加を観察する方法が知られて いる。特にPSV 上昇はDSAによる North American Symptomatic Endarterectomy Trial（NASCET）法の狭 窄率を予測するのに有用とされ, PSV $120 \mathrm{~cm} / \mathrm{s}$ 以上の 場合, DSA による NASCET 法 $50 \%$ 以上, $200 \mathrm{~cm} / \mathrm{s}$ 以 上で $70 \%$ 以上の狭窄と相関することが報告されてい る ${ }^{3,4)}$. しかし, PSV 測定には角度依存性が存在し，さ らにパルス信号と血管走行のなす入射角度が 60 度を超 えると血流速度の誤差が大きくなるため, 入射角度は 60 度未満にすることが必要となる5 ${ }^{5}$. しかし狭窄病変 は立体的な構造をとるため, 狭窄部の血流方向が血管そ のものと平行である場合と, 码腫病変の形状により血管 の走行と一致しない例が存在する，後者の場合にはドプ ラ入射角度を血流方向と血管走行方向のどちらに設定す べきかは定められていない，今回われわれは，血管方向 にドプラ入射角度の補正を行った場合と血流方向にドプ ラ入射角度補正を行った場合の PSV 值を比較して，ド プラ入射角度と内頸動脈狭窄率の関倸について検討を 行った。

\section{対象と方法}

2012 年 4 月〜 2015 年 3 月に頸動脈エコー検査およ びDSA を施行し，内頸動脈起始部に狭窄を認めた 111 例のうち, 狭窄部の血流方向が内頸動脈の走行方向，す なわち内頸動脈近位壁と遠位壁の外膜間距離の中間点を 結ぶ方向が, 血流方向と一致しなかった 50 例（平均年 齢 $71.3 \pm 6.5$ 歳, 男性 46 例）を対象に, 後方視的検討 を行った。

超音波診断機器はSSA-770A（東芝メディカルシステ
ムズ,栃木）のリニア型探触子 $(5 \sim 11 \mathrm{MHz})$ を用いた. パルスドプラ法による狭窄部の PSV 計測は, サンプル ボリュームを最大狭窄部の乱流を十分に覆うように血管 径と同等に設置し，ドプラ入射角度は 60 度以内に設定 した ${ }^{5)}$. 対象のうち，血管方向にドプラ入射角度の補正 を行った群を血管群，血流方向にドプラ入射角度補正を 行った群を血流群と定義した（Fig.1）。DSAによる内頸 動脈起始部狭窄率は NASCET 法（DSA-NASCET）で 評価した ${ }^{6}$.

統計は $\chi^{2}$ 検定㧍よびMann-Whitney のU 検定で両 群の年齢, 性別, 狭窄の局在 (左右), PSV, DSANASCET の差について解析した。 また Pearsonの相関 係数を用いて両群の PSV と DSA-NASCET との相関関 係を求め, 単回帰分析で PSV から DSA-NASCET が予 測可能か評価した，加えて ROC曲線 (receiver operating characteristic curve) で狭窄診断の感度, 特異度, 陽 性的中率 (positive predictive value：PPV), 陰性的中率 (negative predictive value：NPV) および正診率を求め た。統計処理および作図にはIBM SPSS Statistics ver.24.0（IBM Corp., NY, USA）を用い, $p<0.05$ を統 計学的有意とみなした。

\section{結果}

対象のうち，3例は血管方向および血流方向の両者で ドプラ入射角の角度補正を行っており，血管群が 30 血 管，血流群が 23 血管であった。 またDSA-NASCET で は全例 50\%以上の狭窄率を示しており，70\%以上の狭 窄例は血管群が 20 例 (66.7\%), 血流群が 17 例 (73.9\%) であった，両群の背景をみると，年齢，性別，狭窄の局 在に差はなかった. PSV は血管群が $287.4 \mathrm{~cm} / \mathrm{s}$ (中央値) であり, 血流群が $255.2 \mathrm{~cm} / \mathrm{s}$ と有意差は認めず $(p=$ 0.315), DSA-NASCET も前者が $74.1 \%$ ，後者が $75.0 \%$ と同程度の狭窄率であった $(p=0.578)$. しかし, ドプ ラ入射角は血管群が 57.5 度であったのに対し, 血流群 は 54.0 度と有意に後者でドプラ入射角は小さかった $(p=0.0210)$ (Table 1).

血管群の PSV は DSA-NASCET と有意な正の相関が 得られ $(p=0.00470, r=0.502)$, 単回帰分析で DSANASCET の予測が可能であった $\left(r^{2}=0.252\right)$ (Fig.2A). 一方，血流群の PSV と DSA-NASCET の相関をみると， 血管群と同様に有意な正の相関があり $(p=0.000797$, $r=0.650)$, 単回帰分析に扔いても予測が可能で $\left(r^{2}=\right.$ 0.422）（Fig.2B），さらに血管群よりも高い相関が得ら れた。

ROC 曲線による DSA-NASCET 70\%以上狭窄の診断 率をみると, 血管群の曲線下面積 (area under the curve : AUC) は 0.765 と高く（Fig.3A）, PSVのカット 
Table 1 Parameters of angle-adjustment towards the blood flow group and the blood vessel group

\begin{tabular}{lccc}
\hline & $\begin{array}{c}\text { Angle-adjustment towards the } \\
\text { blood vessel group (n=30) }\end{array}$ & $\begin{array}{c}\text { Angle-adjustment towards the } \\
\text { blood flow group (n= 23) }\end{array}$ & $\boldsymbol{p}$ value \\
\hline Male [n (\%)] & $29(96.7 \%)$ & $20(87.0 \%)$ & $0.185^{*}$ \\
Stenosis site [left, n (\%)] & $15(50 \%)$ & $13(56.5 \%)$ & $0.542^{*}$ \\
Age [years, median (range)] & $74(54-83)$ & $70(55-78)$ & 0.171 \\
Angle [degree, median (range)] & $57.5(36-60)$ & $54.0(35-60)$ & 0.021 \\
PSV [cm/s, median (range)] & $287.4(157.2-672.5)$ & $255.2(154-656.3)$ & 0.315 \\
DSA-NASCET [\%, median (range)] & $74.1(55.6-85.5)$ & $75.0(53.0-84.4)$ & 0.578 \\
\hline
\end{tabular}

Mann-Whitney U test. *Pearson's $\chi^{2}$ test

PSV: peak systolic velocity; DSA-NASCET: stenosis rate on NASCET criteria using digital subtraction angiography
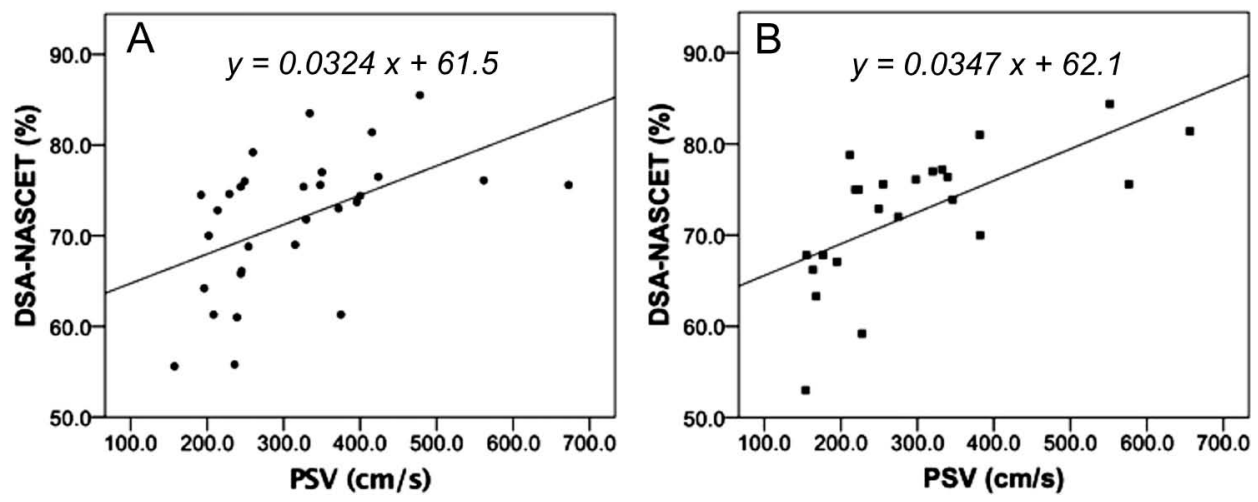

Fig. 2 Relationship between DSA-NASCET and PSV

A: Angle-adjustment towards the blood vessel group $\left(r^{2}=0.252, p=0.00470\right)$

B: Angle-adjustment towards the blood flow group $\left(r^{2}=0.422, p=0.00797\right)$

There was a significant relationship between DSA-NASCET and PSV (simple regression analysis).

PSV: peak systolic velocity; DSA-NASCET: stenosis rate on NASCET criteria using digital subtraction angiography
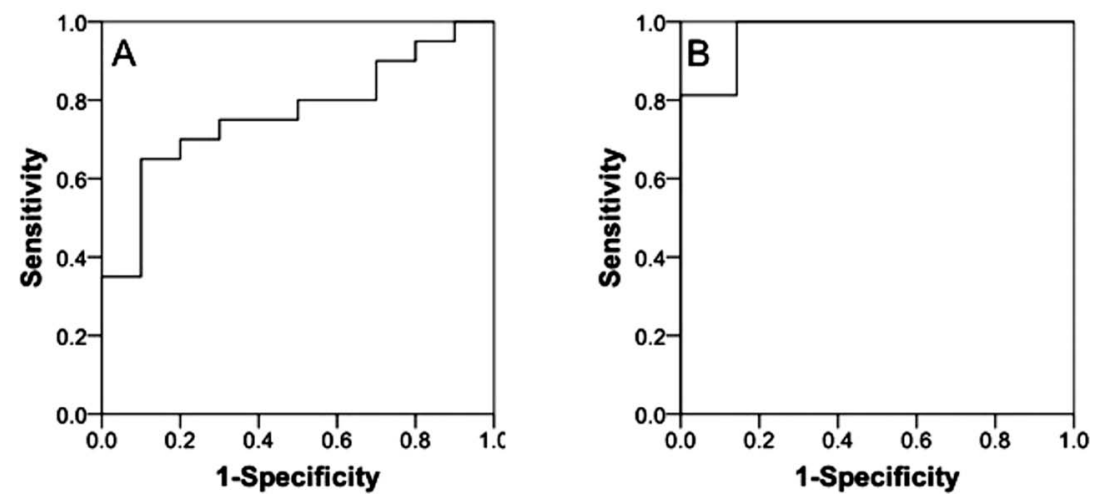

Fig.3 Sensitivity and specificity for diagnosis of internal carotid artery stenosis

A: Angle-adjustment towards the blood vessel group. In receiver operating characteristic curve (ROC), when the cutoff value of PSV was set at $256.9 \mathrm{~cm} / \mathrm{s}$, the sensitivity was $70.0 \%$ and specificity $80.0 \%$ for the diagnosis of DSA-NASCET $\geq 70 \%$.

B: Angle-adjustment towards the blood flow group. In ROC curve, when the cutoff value of PSV was set at $203.5 \mathrm{~cm} / \mathrm{s}$, the sensitivity was $100 \%$ and specificity $85.7 \%$ for the diagnosis of DSA-NASCET $\geq 70 \%$.

PSV: peak systolic velocity; DSA-NASCET: stenosis rate on NASCET criteria using digital subtraction angiography

オフ值を $256.9 \mathrm{~cm} / \mathrm{s}$ とした場合, 感度 $70.0 \%$, 特異度 80.0\%, PPV 87.5\%, NPV 57.1\%, 正診率 73.3\%であっ た。これに対し血流群の AUCは 0.973 と血管群よりも 有用性が高く（Fig. 3B）, カットオフ值を $203.5 \mathrm{~cm} / \mathrm{s}$ と した場合，感度 $100 \%$, 特異度 $85.7 \%$, PPV $94.1 \%$, NPV $100 \%$, 正診率 $95.7 \%$ と, 診断率は血管群よりも
血流群のほうが高かった。

血管方向および血流方向の両者でドプラ入射角の角度 補正を行った 3 例は, 全例男性で左内頸動脈分岐部狭 窄であった． 3 例とも血流方向で計測したドプラ入射角 度は，血管方向のドプラ入射角度よりも低值であり， PSV も低速であった（Table 2). 
Table 2 Sonographic parameters in 3 cases who received measurements of PSV of angleadjustment towards both the blood flow and the blood vessel

\begin{tabular}{ccccccc}
\hline Case & $\begin{array}{c}\text { Age } \\
(\text { years })\end{array}$ & $\begin{array}{c}\text { PSV A } \\
(\mathbf{c m} / \mathbf{s})\end{array}$ & $\begin{array}{c}\text { Angle A } \\
(\mathbf{d e g r e e})\end{array}$ & $\begin{array}{c}\text { PSV B } \\
(\mathbf{c m} / \mathbf{s})\end{array}$ & $\begin{array}{c}\text { Angle B } \\
(\mathbf{d e g r e e})\end{array}$ & $\begin{array}{c}\text { DSA-NASCET } \\
\mathbf{( \% )}\end{array}$ \\
\hline 1 & 75 & 350 & 57 & 320 & 35 & 77 \\
2 & 62 & 561.6 & 60 & 298 & 48 & 76.1 \\
3 & 68 & 672.5 & 60 & 576.4 & 54 & 75.6 \\
\hline
\end{tabular}

PSV A and angle A: angle-adjustment towards the blood vessel, PSV B and angle B: angle-adjustment towards the blood flow

PSV: peak systolic velocity; DSA-NASCET: stenosis rate on NASCET criteria using digital subtraction angiography

\section{考察}

本検討では内頸動脈分岐部狭窄例で，粥状硬化の形状 により血流方向と血管走行が異なる例を対象に検討を行 い,パルスドプラ法による PSV 計測は血流方向にドプ ラ入射角を補正するほうが DSA-NASCET の診断率が 高いことを示した。

頸動脈エコー検査では ECST 法や NASCET 法といっ た径狭窄や area stenosis 法, PSVによる狭窄率診断がな される。なかでも DSA-NASCET の狭窄率を予測する うえで，PSVを用いた診断方法は有用とされている ${ }^{3,4)}$. このため, PSVの計測はより正確に行われることが必 要である。パルスドプラ法による PSVの計測は，血管 内を移動する赤血球の反射を用いて行われる．流体力学 的に血流は円柱状の血管で層流となり，血管の屈曲は血 流の速度分布に変化をもたらすため，パルスドプラ法を 施行する場合は屈曲部を避け，サンプルボリュームを血 管内径の $1 / 2 \sim 2 / 3$ 程度に設定する必要がある ${ }^{5)}$. しか し，狭窄を有する場合は，その形状により血流速度や圧 力変化は多彩なバリエーションを示すことが知られてお $り^{7)}$, 狭窄例を対象とした本検討ではサンプルボリュー ムを血管径と同等に設定した。

一方，パルスドプラ法におけるドプラ信号の計測には 角度依存性があり，血流速度はその実測值をドプラ入射 角度 $\theta$ で除した角度補正が必要となる ${ }^{8)}$. 実際, 糸状ファ ントムを用いた検討では，ドプラ入射角度が増加するほ ど流速が過大評価されることが報告されている ${ }^{8,9)}$ 。 ま た, 実際の内頸動脈狭窄例を対象とした検討においても, 入射角度 45 度と 60 度では DSA-NASCET 狭窄率を疑 うPSVは異なると報告されている ${ }^{10)}$ 。このような角度 補正の不備による血流速度の計測誤差は，60 度を超え ると極端に増加するため，ドプラ入射角度は 60 度以内 に設定することが推奨されている ${ }^{5,11)}$.

頸動脈において䉼状硬化は内頸動脈起始部に好発する が，血管と垂直方向，すなわち狭窄部の血流方向が血管 方向と一致するようにすべてが形成されるわけではな
く, 実際の狭窄病変は複雑な形状をとる。高血圧や高血 糖，脂質異常症，喫煙などの血管障害危険因子により血 管内皮が障害されると, von Willebrand 因子などの働き により血小板の rolling や活性化が生じる。この活性化 血小板は interleukin-1 $\beta$ (IL1- $\beta$ ) や CD40 ligand などの 炎症物質を放出し，血管内皮から動脈硬化を促進する monocyte chemotactic protein-1 (MCP-1) や intercellular adhesion molecule 1（ICAM-1）を誘導する。また血 管内皮障害により low-density lipoprotein cholesterol （LDL-C）が内膜の内側に入り込み，活性酵素の働きに より酸化 LDL に変化し, macrophage によりさらに酸化 LDL が取り込まれ，泡沫細胞を形成する。ささらにコレ ステロールエステルの非特異的蓄積や，血管平滑筋細胞 の遊走および増殖，石灰化などにより籿状硬化が進行し ていく ${ }^{12-14)}$ 。本過程において，粥状硬化内部に多くの 脂質成分を含み，それを取り囲む fibrous cap が薄い場 合は崩壊しやすく ${ }^{14)}$ ，さらには粥状硬化内に出血をき たしているような可動性病変は，形状変化を起こしやす ( ${ }^{15)}$ 。本検討では粥状硬化の性状とその形状について の検討は行っていないが，これらの機序により血管方向 と一致しない狭窄病変が形成される可能性がある。

またわれわれが文献を涉雪しえたかぎりでは，このよ うな例を対象に血管方向と血流方向のそれぞれにドプラ 入射角度を補正して, 狭窄診断率を検討した報告はない. このため，ドプラ入射角度の補正をどちらで行うかは明 らかとなっていない，われわれの検討では血管方向にド プラ入射角度を補正した場合， DSA-NASCET 70\%以上 狭窄と相関が得られ，PSVによる狭窄率診断は有用で あることが示された。しかし血流方向にドプラ入射角度 を補正した血流群は，血管群よりも強い相関があり，そ の診断率も高いものであった。両群の DSA-NASCET による狭窄率およびPSVに有意差はなかったが，ドプ ラ入射角度をみると，血管群は血流群よりも高值であっ た。したがって，血管方向にドプラ入射角度を補正する ことは，狭窄部の PSVに計測誤差が生じていた可能性 がある。 
一方，本検討では日本脳神経超音波学会認定検査士以 外が施行した例も多く含まれており，血管方向で PSV 測定が行われ，かつ認定検査士による二重点検で血流方 向のPSVが再計測された例はわずか 3 例であった。こ のため血管方向と血流方向の両者を計測した症例は 3 例 しか存在しなかった。しかしながら, 本3例においては, 血管方向にドプラ入射角度を補正したPSVは血流方向 に補正したPSVよりも高速であり，過去の報告を裏付 けるものであった。

今後, DSA-NASCET $50 \%$ 以上狭窄を含めた狭窄率別 の検討，血管方向と血流方向の両者を同時に計測した検 討を行い, 粥腫病変の形状により狭窄部の血流方向が血 管の走行と一致しない例に対する適切なドプラ入射角度 の補正方法を明らかにする必要がある。

結論として，本研究ではドプラ入射角度を血管方向に 補正した 30 血管と，血流方向に補正した 23 血管を対 象に, PSVとDSA-NASCET $70 \%$ 以上狭窄の診断率を 検討し，血流方向に補正するほうがより高い診断率が得 られることが示された。

本論文の要旨は第 35 回日本脳神経超音波学会総会 （2016 年 6 月，横浜）で発表した。

文中, peak systolic velocityは，脳神経超音波用語集 における peak systolic flow velocity と同義である。

\section{○参考文献}

1) Mitchell AM, Jones AE, Tumlin JA, et al.: Incidence of contrastinduced nephropathy after contrast-enhanced computed tomography in the outpatient setting. Clin J Am Soc Nephrol
2010; 5: 4-9.

2) Hankey GJ, Warlow CP, Sellar RJ: Cerebral angiographic risk in mild cerebrovascular disease. Stroke 1990; 21: 209-222.

3) AbuRahma AF, Srivastava M, Stone PA, et al.: Critical appraisal of the Carotid Duplex Consensus criteria in the diagnosis of carotid artery stenosis. J Vasc Surg 2011; 53: 53-59.

4) Koga M, Kimura K, Minematsu K, et al.: Diagnosis of internal carotid artery stenosis greater than $70 \%$ with power Doppler duplex sonography. AJNR Am J Neuroradiol 2001; 22: 413417.

5）古賀政利：血流速度，日本脳神経超音波学会・栓子検出と治 療学会合同ガイドライン作成委員会：頸部血管超音波検査ガ イドライン. Neurosonology 2006; 19: 59-61.

6) North American Symptomatic Carotid Endarterectomy Trial (NASCET) Streeing Committee: North American Symptomatic Carotid Endarterectomy Trial. Methods, patient characteristics, and progress. Stroke 1991; 22: 711-720.

7）菅原基晃，仁木清美，大手信之：知っておきたい流れの性質， イメージで理解する心エコー・ドプラ・循環力学, 東京 : 文 光堂, 2011, p139-158.

8）宮本倫聡，小谷和彦, Shuumarjav UURTAYA, 他：角度補正 による最大流速の過大評価. Jpn J Med Ultrasonics 2012; 39: 627-630.

9) Eicke BM, Kremkau FW, Hinson H, et al.: Peak velocity overestimation and linear-array spectral Doppler. J Neuroimaging 1995; 5: 115-121.

10) Tola M, Yurdakul M: Effect of Doppler angle in diagnosis of internal carotid artery stenosis. J Ultrasound Med 2006; 25: 1187-1192.

11) Terminology and Diagnostic Criteria Committee, Japan Society of Ultrasonics in Medicine: Standard method for ultrasound evaluation of carotid artery lesions. J Med Ultrason 2009; 36: 219-226.

12) Gawaz $M$, Langer $H$, May AE: Platelets in inflammation and atherogenesis. J Clin Invest 2005; 115: 3378-3384.

13）杉本充彦：血栓形成過程：オーバービュー．脈管学 $2011 ; 51$ : 275-282.

14) 山田信博：動脈硬化発症病態としての生活習慣病. 日薬理誌 2008; 131: 89-91.

15) Kume S, Hama S, Yamane K, et al.: Vulnerable carotid arterial plaque causing repeated ischemic stroke can be detected with B-mode ultrasonography as a mobile component: Jellyfish sign. Neurosurg Rev 2010; 33: 419-430. 